\title{
Research of Communication Management Mechanism of Virtual Teams Project (VTP) in Across- Area Implementing (AAI)
}

\author{
Yuehong Xu \\ ${ }^{1}$ Management School of MinzuUniversity of China, Beijing, China, \\ Email:nancyyh@qq.com
}

\begin{abstract}
This electronic document summarizesthe concepts and characteristics of Informationize Projects(IP) in Across-area implementing (AAI) first. Then state and analyze the communication problems along life cycle of VTP in AAI,from starting,developing to implementing. Finally propose relevant communication mechanisms of resolving tactics which include structure mechanism and procedure mechanism.
\end{abstract}

$\begin{aligned} & \text { Keywords-Project management; } \\ & \text { management ;Across-area implementing }\end{aligned}$
TeamsProject (VTP)

\section{INTRODUCTION}

With the economic globalization and the rapid progress of information and communication technology, sky rocketing software development companies apply across-area virtual team into project organizational structure. Across-area virtual team refers to a group of people with different abilities as well as resources, and they work together across time, space, organizational boundaries and countries in order to complete specific tasks. At present, the virtual team made up of team members in different regions implementing informatization project widely exists in software development companies with branch services and transnational corporations. Such cross-area virtual team is able to help companies to react flexibly and rapidly in highly variable and severe market competition so as to reduce the cost and improve resource utilization. However, confined by regions and different roles, such project will bring new challenges for the project manager in terms of project communication management comparing to traditional project. The communication management is not limited to the communication between the applicant and construction contractor while the internal communication of construction contractor is of top priority.

In addition, the investment of government departments at all levels and enterprises paid in recent years is climbing and they set up a series of informationization project such as e-Government, e-commerce, ERP, and CRM. However, the fact which cannot be ignored is that the scale of these informationizaiton projects is extending while the complexity is increasing. Besides, there are also problems such as multiple participants, uncertain demand, lack of information technology experts as well as project management talents and therefore, the informationization project construction effect is barely satisfactory.

In informatization project management, communication is a soft index yet the communication function cannot be quantified with invisible effect. In successful IT project, people cannot feel the role communication plays yet in failed IT projects they can find the hazard of miscommunication. Without good communication, there shall be restrictions in terms of project development as well as interpersonal relationship improvement. We can say that, in informatization project, the communication effect determines the success or failure of the whole project and affects the cost, progress because miscommunication is one of the biggest risks in IT project. Currently, in the cross-area informatization project implementation, how to effectively realize communication management and set up meaningful cross-area IT project communication management system is helpful to improve the efficiency, carry out effective construction investment and better complete the task.

\section{PROBLEM ANALYSIS FOR THE CROSS-AREA}

\section{INFORMATIZATION PROJECT COMMUNICATION}

\section{MANAGEMENT}

In cross-area informatization project communication management implementation, the developer and the implementation group are notin the same place and the developer completes the system development and test work while the implementation group completes the demand analysis as well as installation and commissioning on the scene. In the course of project development and implementation, cross-area teams haveto carry out frequent internal communication. The implementation group should convey the information during the analysis period to the developer while the developer has to help the implementation group have a clear understanding of the concrete functions of various modules as well as the connotation of basic database and the then the communication management becomes incredibly comp licated. All relevant stakeholders have to be ready to send and receive relevant project information 
and know that the effect on the project progress and final result they shall create.

\section{A. Characteristics of the cross-area informatization project communication management}

The comple xity and systematicity shall become the most important characteristics:

Complexity: Each informatization project is closely related to complicated software and hardware platform, flexible and expandable system structure, and underlying data. At the same time, the demand to clear the characteristics of team members makes the construction progress complicated. Therefore, the management communication hasto have a clear mind of the relationship among coordinating organization and project stakeholders so as to have expected effect.

Systematicity: The cross-area informatization project is an open and complicated system. The establishment of this project involves social political, economic and cultural factors. Besides, informatization project containing engineering construction shall affect ecological environment and resource generation. Therefore, the project communication should start from the whole interest adopting systematic thinking method so as to comprehensively carry out effective management.

\section{B. Problem analysisfor the cross-area informatization project communication management}

\section{1) Existing communication problems in project initiating}

According to standard theory and practical experience of software project management, the project initiating stage is one of the most important stages in the demand analys is process of the whole lifecycle. If it is properly dealt with, we are able to develop excellent software products and satisfy both the applicant and construction contractor, or it will bring along with credit loss. If there should be an obvious deviation between the final delivering software system and real customer de mand, large damages will occur. Any modifications on the demand caused by misunderstanding will lead to reprocessing of subsequent design, development and test which shall cost more time and resources and cannot be borne by both of them. The demand analysis has laid the foundation for software engineering and project management and so the communication management is of great significance. Communication problems in this stage show as follows:

Firstly, insufficient content and misunderstanding: the informatization project involves integration of various software platformsand sometimes they are bought by the applicant and the construction contractor is responsible to apply. However, in the course of buying software platform, only the compatibility of single platform and operation system is taken into consideration while the compatibility of various platforms and operation systems are ignored. In the beginning of project construction, the applicant only provides brief introduction to the construction contractor without detailed communication in terms of software platform version number and system support and the incompatibility as well as misunderstanding may lead to mistakesif they are not timely found or advanced the project shall be severely affected.

Secondly, non-continuous communication process and non-smooth cohesion: if the applicant only takes construction effect into key performance indicator for employees in the information department but not business department, employees in the business department will have high enthusiasm. In the course of analysis demand, if workers of applicant side are busy or there should be conflicts, they won't put enthusiasm into project or they may replaced by others to participate in the research meeting, which shall lead to the condition that there will be obvious defects.

Thirdly, improper communication objects: If the demand put forward by the sales man of the applicant side, then the demand cannot stand for the opinion of leaders of the applicant and may lead to repeated demand.

2) Existing communication problems in the course of project development

The design, development, test and factory process are regarded as the project development stage and the work volume during this stage occupies $40-50 \%$ of the whole life cycle. Main work completed in this project includes:

The project developer carries out detailed design based on the User Requirements Statements and sets up planning database to initially identify the contents connecting to other system interfaces as well as the realization approach; carry out detailed design in terms of system technology structure, database storage structure, application function, and operation interface mode to finally form Systematic design statement;

According to Systematic design statement, we carry out code development as well as development realization.

The project test group carry out testing and after various iteration, the final factory copy is finished.

In this stage, we adopt telephone, email and instant communication tools (such as QQ or MSN), project meeting and text (such as project progress report) etc.

In the course of detailed design progress and subsequent code development, the applicant and the construction contractor have to carry out frequent communication and following problems will occur if there should be improper communication:

Firstly, the internal communication of the construction contractor is not timely. Even though most of the members in the project development team have certain knowledge, they are not granted with opportunities to carry out face to face communication with customers so the demand of customers come from User Requirements Statements or guided by development manager. Meanwhile, the informatizationproject is complicated so some details cannot be properly dealt with becausethe construction contractor team members are not in the same place. As a result part of the demand cannot totally match the function design and database design. Even though, they can work extra time to carry out modification there 
should be increasing over time pay as well as transportation cost.

Secondly, the internal communication of the construction contractor is not in the place. After coming to the code development stage, it has a long duration and the implementation manager can only know the development progress based on the weekly report. In terms of project information releasing, the implementation manager and the developer manager do not frequently release information, especially the information of other side. What's more, in terms of report progress, only the work completed of last week and the work plan of next week are described without key resources as well as preparation (especially the demand of the applicant and construction contractor) and therefore the potential risk cannot be fully identified. So, team members are not aware of the progress, especially the information of how the construction contractor is implementing the project. As a result, team members cannot initiatively think about the problem, they passively receiver the order of the superior and cannot put forward useful suggestions for the whole project as well as subsequent work. Furthermore, the implementation manager holds the view that the development progress is a black box for him, and cannot flexibly answer customers which may cause unnecess ary worry and mistrust.

Thirdly, there is information distortion and missing: even though the developer manager comes to the scene to participate in the reviewing of User Requirements Statements with customers and construction contractor. However, there should be information distortion and missing while conveying information to the developer.

3) Communication problems in the course of project implementation

According to the actual situation of informatization project, we can call the monitoring processes, execution and closure process as the project implementation phase. It is mainly responsible to systematically carry out field work, namely to carry out debugging and integrate the data so as to complete the installation; field system test; system function inspection; system commissioning and user training and final testing.

At this stage, communication means such as online interactive systems, projects, meetings, phone calls, email, instant messaging (MSN or QQ), documentation (such as systemhelp manual, project progress reports are adopted.

During the project implementation phase, whether the final feasible application can meet the demand of the applicant depends on the work result and quality of the start-up stage as well as the development stage which is also closely related to the work effect of the implementation stage. Therefore, in this stage, we have to carry out frequent internal and external communication work which will also ignite a dazzling array of communication problems:

Firstly, different participants in the implementation stage will bring along with different understandings. The detailed design, code development, test stage and installation of cross-area project are undertaken by different designers andimplementation groups which shall bring the problems that the implementation members are familiar with the actual demand of customers yet they do not participate in the detailed design and cannot have a good knowledge of the connotation of the basic function of various function models as well as the structure connotation of basic database. If the implementation members do not have enough communication with the developer in the design and development stage, especially the development stage, there should be misunderstandings even with the guidance of Procedural Design Specification and System Help Manual if they are not systematically trained.

Secondly, the communication gap emerges in the implementation stage. For example, in the installation debugging process of distribution system project,we have to put the grid model data (such as substation, distribution room, Tower, switch, and knife gate etc) into the distribution planning system in one shot and realize subsequent data updating which need a series data processing procedure. However, inusing such procedure, the developer and construction contractor both hold the idea that it should be completed by the other side. As a result, there is excessive rework which increases the project cost.

Thirdly, thecommunication mechanism in the project implementation is imperfect which will cause information delay and missing. Some original project testing functions which have been passed in the construction contractor side cannot be used in the site and some functions should be modified. Concerning these problems, the project developer is responsible to follow up the solution. The project construction contractor will carry out communication by e-mail and the communication problems (such as problem serial number, problem description, discoverer, modifier, modification time etc) are listed in a problem document. The problem discoverer is responsible to send the development manager by e-mail and the manager will send to all the developers so as to carry out the modification. The problem list document is a shared file and lots of people have the access to carry out modification and sometimes there should be covering and information missing; the problem list is conveyed by e-mail and the first receiver is the development manager yet sometimes the development manager cannot receive the e-mail in the first time which shall cause problem modification delay.

\section{The communication management mechanism of cross-area informatization project}

In order to effectively solve the communication problem of cross-area informatization project, we have to regulate such communication mechanism from the structure and procedure.

\section{1) Structural mechanism of cross-area informatization project communication management}

Overall principle: Based on the principle of overall planning, step-by-step and deman driven, we set up a communication principle with full communication, perspective taking, pulling together, shared 
responsibility and shared results so as to set up all level responsibility mechanism and ensure that people in each department can participate. According to the characteristics of team, we set up targeted, full communication approach, communication management institution and communication management planning (see in table 1)

TABLE I. THE STRUCTURAL MECHANISM OF CROSS-AREA INFORMATIZATION PROJECT COMMUNICATION MANAGEMENT

\begin{tabular}{|c|c|c|c|c|c|c|c|}
\hline \multicolumn{3}{|c|}{ Project communication approach } & \multicolumn{5}{|c|}{$\begin{array}{l}\text { Online interactive system, project meeting, telephone, email, instant communication } \\
\text { tools (QQ or MSN), electronic document etc. }\end{array}$} \\
\hline \multirow[t]{3}{*}{$\begin{array}{l}\text { Project } \\
\text { communic } \\
\text { ation } \\
\text { manageme } \\
\text { nt system }\end{array}$} & \multicolumn{2}{|c|}{ regular meeting system } & \multicolumn{5}{|c|}{$\begin{array}{l}\text { Regularly hold project meetings and the project manager should organize both the } \\
\text { members to attend. Carry out communication about the project progress; recognize } \\
\text { potential risk and write potential risk tracking report; comment on the work quality; } \\
\text { solve difficulties (submit to the leader group based on actual reality); adjust the progress } \\
\text { plan if necessary and report the project progress to the leader group. In the demand } \\
\text { analy sisand site implementation stage, the meeting should be hold weekly and in the } \\
\text { design and development stage, the meeting should be hold based on requirements. }\end{array}$} \\
\hline & \multicolumn{2}{|c|}{$\begin{array}{l}\text { Project progress report } \\
\text { system }\end{array}$} & \multicolumn{5}{|c|}{$\begin{array}{l}\text { The implementation manager and development manager of the construction contractor } \\
\text { take a week as the unit to write work report and the implementation manager is } \\
\text { responsible to summarize and send it to the project manager of the applicant side every } \\
\text { Friday. In addition, twoproject progress reports should be submitted to the work logging } \\
\text { system. }\end{array}$} \\
\hline & \multicolumn{2}{|c|}{ Information releasing system } & \multicolumn{5}{|c|}{$\begin{array}{l}\text { 1. The cross-area information releasing should adopt informationization tool so as to } \\
\text { ensure that the information is released timely with feedback. } 2 \text {. The contents of key } \\
\text { sectors such as customer demand, detailed design should be properly transferred so as to } \\
\text { ensure the normal operation of subsequent work. } \\
\text { 3. The information releasing should be comprehensive and clear. In project phase } \\
\text { dominated by one certain team, the comprehensive information releasing is of great } \\
\text { significance. }\end{array}$} \\
\hline \multirow{8}{*}{$\begin{array}{l}\text { Project } \\
\text { communic } \\
\text { ation } \\
\text { manageme } \\
\text { nt } \\
\text { plan }\end{array}$} & \multirow{8}{*}{$\begin{array}{l}\text { In order } \\
\text { to } \\
\text { completely, } \\
\text { timely, and } \\
\text { accurately } \\
\text { deliver the } \\
\text { information } \\
\text { to all } \\
\text { relevant } \\
\text { stakeholder } \\
\text { s }\end{array}$} & $\begin{array}{l}\text { Communicati } \\
\text { on type }\end{array}$ & Frequency & Time & Content & Input & Output \\
\hline & & $\begin{array}{l}\text { Leader Group } \\
\text { Symposium }\end{array}$ & Month & $\begin{array}{l}\text { 1st Week } \\
\text { Monthly }\end{array}$ & $\begin{array}{l}\text { Schedule Update; } \\
\text { key issues }\end{array}$ & $\begin{array}{l}\text { Meeting Agenda; } \\
\text { Meeting materials }\end{array}$ & $\begin{array}{l}\text { Meeting } \\
\text { Minutes }\end{array}$ \\
\hline & & $\begin{array}{l}\text { Project } \\
\text { meeting }\end{array}$ & Week & & $\begin{array}{l}\text { Progress review, } \\
\text { problem discussion }\end{array}$ & & $\begin{array}{l}\text { Meeting } \\
\text { Minutes }\end{array}$ \\
\hline & & Training & $\begin{array}{l}\text { As } \\
\text { Needed }\end{array}$ & As Needed & As Needed & Training material & $\begin{array}{l}\text { Effect } \\
\text { Evaluation }\end{array}$ \\
\hline & & Interview & $\begin{array}{l}\text { As } \\
\text { Needed }\end{array}$ & As Needed & As Needed & & $\begin{array}{l}\text { Meeting } \\
\text { Minutes }\end{array}$ \\
\hline & & $\begin{array}{l}\text { report-back } \\
\text { meeting }\end{array}$ & $\begin{array}{c}\text { As } \\
\text { Needed }\end{array}$ & As Needed & $\begin{array}{l}\text { Project Progress } \\
\text { Report }\end{array}$ & Report material & $\begin{array}{l}\text { Meeting } \\
\text { Minutes }\end{array}$ \\
\hline & & $\begin{array}{l}\text { Project } \\
\text { meeting }\end{array}$ & Week & Once a week & $\begin{array}{l}\text { Progress, problem } \\
\text { and decision etc }\end{array}$ & Meeting Minutes & $\begin{array}{l}\text { Weekly } \\
\text { project } \\
\text { progress }\end{array}$ \\
\hline & & & As Needed & As Needed & As Needed & As Needed & \\
\hline $\begin{array}{l}\text { Accoun } \\
\text { tability } \\
\text { arrange } \\
\text { ment }\end{array}$ & $\begin{array}{l}\text { See } \\
\text { figure } 1\end{array}$ & \multicolumn{6}{|c|}{$\begin{array}{l}\text { Project leader: Concerning the complexity of informationization project, we have to set up a project leader } \\
\text { to be responsible for the project progress and project implementation as well as project quality. The project } \\
\text { leader group stands for the management level; Examine and approve the overall plan, the project } \\
\text { implementation project; make project acceptance criteria; responsible for the decision making of major }\end{array}$} \\
\hline
\end{tabular}




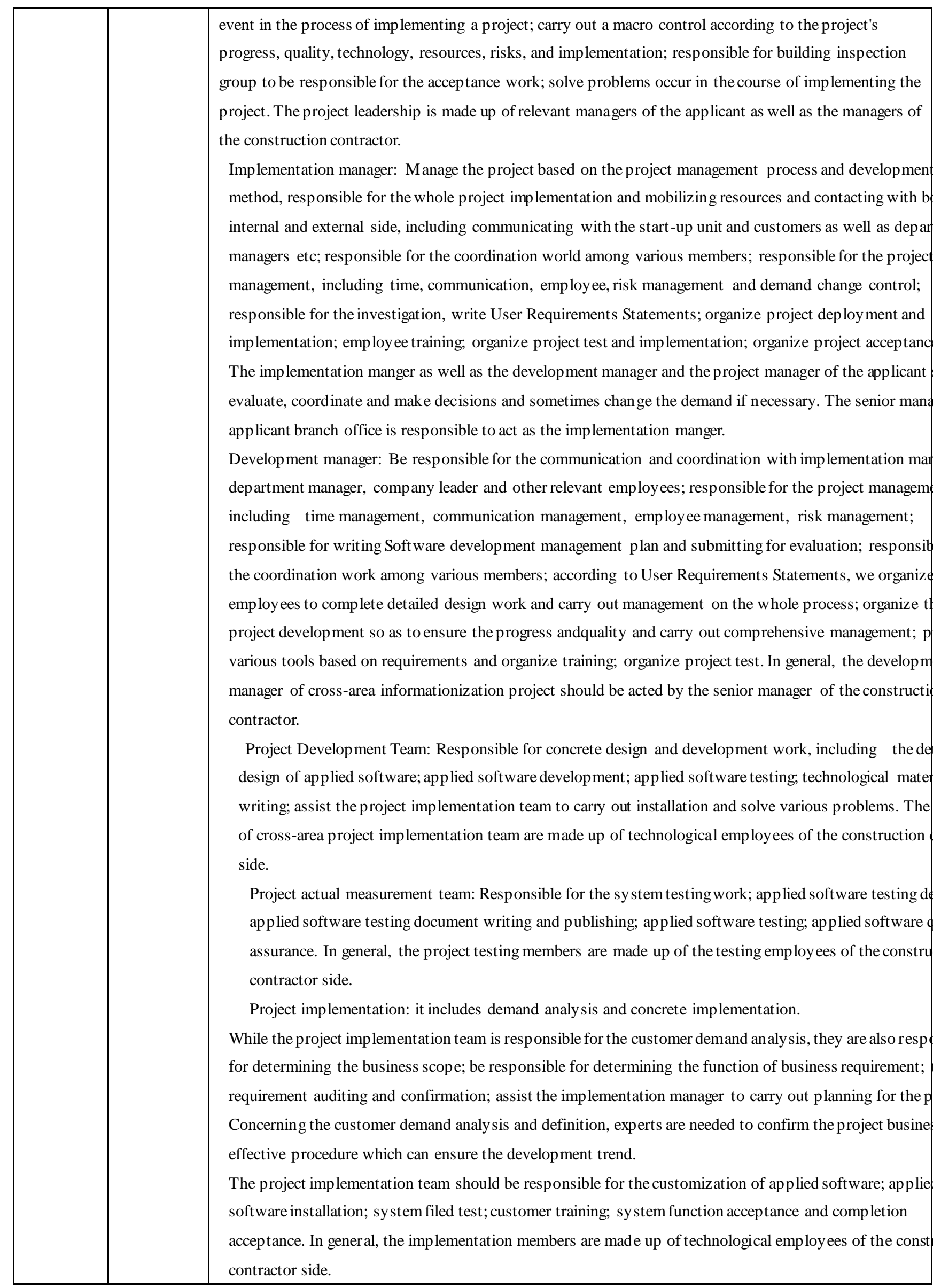




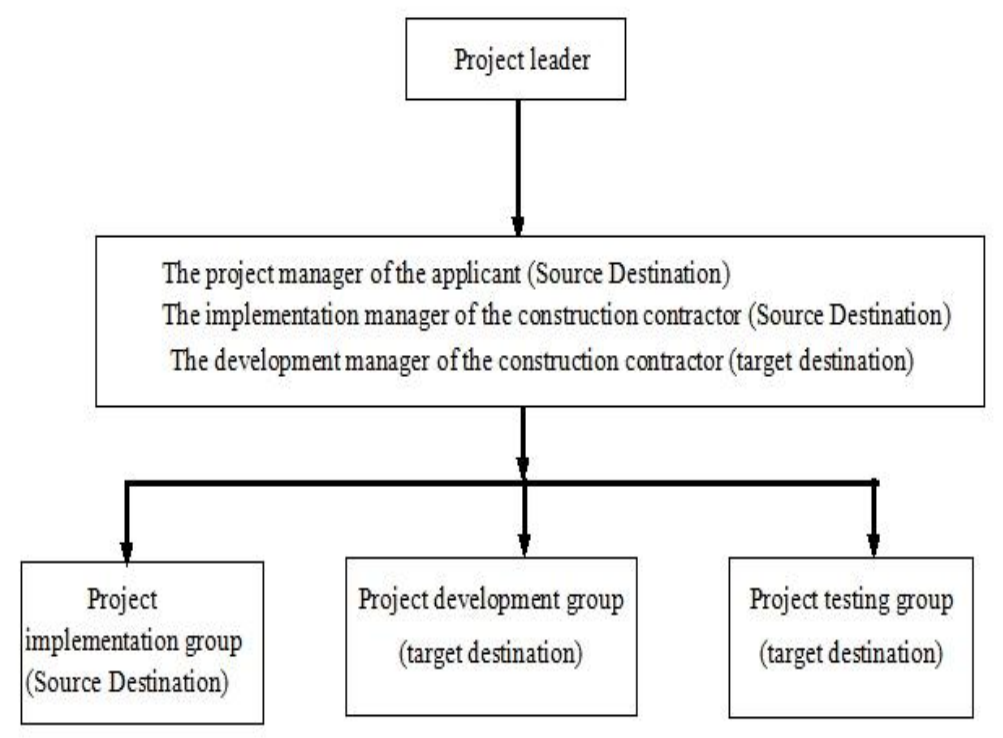

Figure 1. Accountability arrangements of cross-area informationization project in terms of organizational level

\section{2) Procedural mechanism of cross-area informationization project communication management}

TABLE II. PROCEDURAL MECHANISM OF CROSS-AREA INFORMATIONIZATION PROJECT COMMUNICATION MANAGEMENT

\begin{tabular}{|c|c|c|c|c|}
\hline & & \multicolumn{2}{|l|}{ The applicant } & Construction contractor \\
\hline \multirow[t]{3}{*}{$\begin{array}{l}\text { start-up } \\
\text { phase }\end{array}$} & \multirow[t]{2}{*}{$\begin{array}{l}\text { Initial } \\
\text { meeting }\end{array}$} & \multicolumn{2}{|c|}{$\begin{array}{l}\text { 1. Concerning the business application scope, we have to } \\
\text { determine the participants in advance and carry out adjustment if } \\
\text { necessary so as to ensure that all core employees can participate } \\
\text { in the project in the whole process. } \\
2 \text {. Int roduce the basic condition of the side as well as the project } \\
\text { preparation condition and submit relevant materials. }\end{array}$} & $\begin{array}{l}\text { 1. Report the project condition and collect opinions of the } \\
\text { construction contractor in terms of basic implementation } \\
\text { plan etc } \\
\text { 2. Make correct management policy and find out key } \\
\text { stakeholders so as to make their participation. } \\
\text { 3. Choose professional project manager who is familiar with } \\
\text { business as well as project development and management } \\
\text { procedure. }\end{array}$ \\
\hline & & \multicolumn{3}{|c|}{$\begin{array}{l}\text { 1. Both participants should have consensus and clear technological understanding; } \\
\text { 2. Determine the basic organization means and project schedule. Make project management communication regulations as well } \\
\text { as communication management plan together. }\end{array}$} \\
\hline & $\begin{array}{l}\text { Demand } \\
\text { analysis }\end{array}$ & $\begin{array}{l}\text { 1. The project manager of the applicant } \\
\text { leads the project team of construction } \\
\text { contractor to hold research conference } \\
\text { and the business department employees } \\
\text { come to the scene for confirmation and } \\
\text { explain the unexpected function. } \\
2 . \text { Ensure that core business men can fully } \\
\text { participate in the project demand } \\
\text { discussion. } \\
3 \text {. The project relevant stakeholders } \\
\text { should unify the requirement in advance } \\
\text { so as to ensure the accuracy and integrity } \\
\text { as well as compliance of the applicant. }\end{array}$ & $\begin{array}{l}\text { 1. In the demand res } \\
\text { contractoris respon } \\
\text { demonstration of or } \\
\text { 2. Discuss about the } \\
\text { ask his opinions so } \\
\text { 3. Evaluate the tech } \\
\text { modules are include } \\
\text { research plan. } \\
\text { 4. Evaluate the busir } \\
\text { the project plan to fi } \\
\text { and customers of di } \\
\text { 5. Clear up material } \\
\text { project manager an } \\
6 \text {. Based on the requ }\end{array}$ & $\begin{array}{l}\text { arch meet ing, the implementation manager of the construction } \\
\text { ible to carry out system function introduction as well as the } \\
\text { ginal system. } \\
\text { research plan and arrangement with the project manager and } \\
\text { s to make concrete meeting time and employee arrangement. } \\
\text { ological personnel of the applicant and if various systems and } \\
\text {, we have to determine the hardware module based on the } \\
\text { ess men of the applicant side and carry out communication on } \\
\text { ally form customer demands based on classified businesstype } \\
\text { ferent levels; } \\
\text { and talk about the research as well as customer demands with } \\
\text { relevant leaders to take customer advices. } \\
\text { rement, write the demand statement and ask the opinion of }\end{array}$ \\
\hline
\end{tabular}




\begin{tabular}{|c|c|c|c|}
\hline & & & $\begin{array}{l}\text { project manager of the applicant side so as to finally submit formal demand. } \\
\text { 7. The implementation manager completes the User Requirement Statements and } \\
\text { organizes customer demand. After ensuringthe customer demand, the development } \\
\text { manager and project core members hold the appraisalmeeting. Based on the } \\
\text { reviewing result, we modify the User Requirement Statement and publish baseline } \\
\text { 3. }\end{array}$ \\
\hline & \multicolumn{3}{|c|}{$\begin{array}{l}\text { 1. Before the demand research meet ing, we have to clear the meeting schedule and problems need to be discussed and inform the } \\
\text { participants. Relevant meeting materials should be sent to relev ant people in advance and ask them to read so as to decrease } \\
\text { meeting time and make good preparation. } \\
\text { 2. Concerning the compatibility issue, the applicant side and construction contractor should carefully talk about it. And the } \\
\text { project manager of the applicant as well as the implementation manager and buyers of construction contractor should carry out } \\
\text { discussion so as to timely find out potential problems so as to solve them and ensure a stable working environment. }\end{array}$} \\
\hline $\begin{array}{l}\text { Development } \\
\text { phase }\end{array}$ & \multicolumn{2}{|c|}{$\begin{array}{l}\text { 1. Ensure that all core business men should } \\
\text { fully participate in the project requirement } \\
\text { discussion. } \\
\text { 2. Participate in the interview meeting of User } \\
\text { Requirement Meeting. } \\
\text { 3. Regularly participate in the project } \\
\text { meeting. }\end{array}$} & $\begin{array}{l}\text { including the schedule variance and form iteration copy. Besides, the } \\
\text { implementationmanager should arrange the implementation engineer to } \\
\text { download the latest copy of code and carry out installation. } \\
\text { 2. The implementation manager should be familiar with the development } \\
\text { function so as to answer the problems cust omers might put forward in the } \\
\text { weekly report meeting and show them the new functions if necessary. }\end{array}$ \\
\hline $\begin{array}{l}\text { Implementation } \\
\text { phase }\end{array}$ & $\begin{array}{l}\text { 1.Participate in the } \\
\text { function acceptance. } \\
\text { 2.Participate in the } \\
\text { completion } \\
\text { acceptance. } \\
\text { 3. articipate in the } \\
\text { system trialoperation } \\
\text { as well as customer } \\
\text { training. } \\
\text { 4. Timely put forward } \\
\text { modification. } \\
\text { 5.Participate }\end{array}$ & \multicolumn{2}{|c|}{$\begin{array}{l}\text { 1. The development manager is responsible to lead the core members to carry out system function and } \\
\text { database structure training so as to ensure that all implementation manager and implementation team } \\
\text { members are fully familiar with them and then the field work can be carried out. } \\
\text { 2. Set up a professional QQ group for convenient communication and discussion so as to improve the } \\
\text { work efficiency. } \\
\text { 3. Adopt open source BUG management system JIRA to manage the problems. The implementation } \\
\text { members, development members, and test ing members carry out interactive communication about } \\
\text { various problems (such as BUG, new demand and change request). Through this system, the } \\
\text { implementation manager, development manager, testing employee and implementation employee can } \\
\text { track the problem and solution progress; the development employee can timely have a good } \\
\text { knowledge of the description of the problem bythe notifications (short messages, e-mail and online } \\
\text { checking). The managers of the construction contractor can know the problem quantity, av erage time } \\
\text { to deal with the problems and provide support. }\end{array}$} \\
\hline
\end{tabular}

\section{REFERENCES}

[1] Xu Lanping Brief Discussion on communication management in software development project. China Management Informationization, 2011, 14 thVolume 14thterm: 97 98.

[2] (America) Project Management Institute. Project Management Body of Knowledge4thedition Beijing:Publishing House of Electronics Industry, 2009. 243 271.

[3] Jerzy Stawicki. Project communication-Theory and Practice(second part). Project Management Techniques, 2008, 6th Volume 6thterm: $72 \sim 73$.

[4] Yu Qian, Jiangbo. Effective communication management based on the software development project.Computer and Information Technology, 2005,3rdterm: 69 70.
[5] Dong XiongbaoCommunication management problems and countermeasures for the information system development project management. Market Modernization, 2007, December: $166 \sim 167$.

[6] Peng Wei. Brief discussion on the communication management in the software development project. Fujian Computer. 2010, 1stterm: $70 \sim 74$.

[7] Xu Zhiyng. Teng Teng. System construction of information communication management in the software development project implementation. Soft ware Guide, December 2007: 81 82.

[8] Zhao Yuan, Shi Bingdong. Brief discussion on the communication management of software project. Science and Technology Innovation Herald, 2010, 5thterm: 191 191. 